\title{
高強度レーザー誘起表面プラズモン共鳴による高速電子の高効率生成
}

\author{
三島陽介 ${ }^{1}$ ，羽原 英明 ${ }^{1}$ ，Prashant K. SINGH ${ }^{2}$ ，Amitava ADAK ${ }^{2}$ ，Gourab CHATTERJEE ${ }^{2}$, \\ Amit D. LAD $^{2}$ ，P. BRIJESH ${ }^{2}$ ，Malay DALUI ${ }^{2}$ ，井上 雅彦 ${ }^{3}$ ，J. JHA ${ }^{2}$ ，Sheroy TATA ${ }^{2}$ ， \\ T. Madhu TRIVIKRAM ${ }^{2}$ ， M. KRISHNAMURTHY ${ }^{2}$ ，G. Ravindra KUMAR ${ }^{2}$ ，田中 和夫 ${ }^{1}$ \\ ${ }^{1}$ 大阪大学大学院 工学研究科電気電子情報工学専攻 (₹565-0871 大阪府吹田市山田丘2-1) \\ 2 夕夕基礎研究所核物理原子物理学専攻 (テ400-005 ムンバイコラバホミババ通り1) \\ 摂南大学 理工学部電気電子工学科 († 572-8508 大阪府寝屋川市池田中町17-8)
}

\section{Efficient Production of Fast Electron Via Surface Plasmon Resonance Induced by Intense Laser Light}

Yosuke MISHIMA, ${ }^{1}$ Hideaki HABARA, ${ }^{1}$ Prashant K. SINGH,${ }^{2}$ Amitava ADAK,${ }^{2}$ Gourab CHATTERJEE, ${ }^{2}$ Amit D. LAD, ${ }^{2}$ P. BRIJESH, ${ }^{2}$ Malay DALUI, ${ }^{2}$ Masahiko INOUE,${ }^{3}$ J. JHA,,${ }^{2}$ Sheroy TATA,${ }^{2}$ T. Madhu TRIVIKRAM,${ }^{2}$ M. KRISHNAMURTHY, ${ }^{2}$ G. Ravindra KUMAR, ${ }^{2}$ and Kazuo A. TANAKA ${ }^{1}$

${ }^{1}$ Division of Electronic, Information, and Energy Engineering, Graduate School of Engineering, Osaka University, 2-1 Yamadaoka, Suita, Osaka 565-0871, Japan

${ }^{2}$ Department of Nuclear and Atomic Physics, Tata Institute of Fundamental Research, 1 Dr. Homi Bhabha Road, Colaba, Mumbai 400 005, India

${ }^{3}$ Department of Electrical and Electronic Engineering, Faculty of Science and Engineering, Setsunan University, 17-8 Ikedanakamachi, Neyagawa, Osaka 572-8508, Japan

(Received May 12, 2015)

\begin{abstract}
High-energy electrons are generated when a high intensity $\left(10^{19} \mathrm{~W} / \mathrm{m}^{2}\right), 30$-femtosecond laser pulse irradiates a grating target at the resonant condition of surface plasmon excitation. The number of observed electrons for the grating target is 16 times higher than that for a plane foil target. A finite difference time domain simulation demonstrates a sharp dip of reflectivity by surface plasmon excitation at this condition, and a particle-in-cell simulation well reproduces the trend of electron energy spectra measured in the experiment. The acceleration mechanism of the fast electrons can be explained by $\mathrm{J} \times \mathrm{B}$ acceleration, based on the agreement of the measured slope temperatures with those provided by numerical scaling laws.
\end{abstract}

Key Words: Intense laser, Surface plasmon resonance, Fast electron, Grating

1. はじめに

集光強度が $10^{18} \mathrm{~W} / \mathrm{cm}^{2}$ を超える高強度レーザーパルス とプラズマの相互作用によって加速される電子のエネル

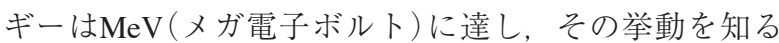
には相対論的な取り扱いを必要とする。この高速電子は 高エネルギー密度物理や準単色ビームを用いた高密度プ ラズマ診断，次世代エネルギーとして期待されるレー ザー核融合やプラズマフォトニックデバイスを用いた ビーム制御といった観点からも精力的に研究がおこなわ れている ${ }^{1,2)}$ ，また，高強度レーザー照射時に高速電子 と同様に生成される高エネルギーイオン・硬X線は, ブ ラッグピークを利用した粒子線がん治療, 放射性同位元 素の生成, 実験室宇宙物理, 加速器へ入射する高輝度粒 子線源として及びプラズマ中の電磁場計測などに用いら

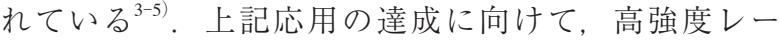
ザー生成高エネルギー粒子ビームのさらなる高輝度化が 求められている.

ターゲット表面にナノ構造をもたせた場合，平板ター ゲットと比較して，生成される高速電子のフラックスが 大幅に増加する研究が多数報告されている。ナノ構造の 一例として挙げられるナノワイヤー ${ }^{6)}$ ，フォーム イクロスフィア などは, 一般的に全てランダム構造で ある。一方，2光束干渉法などで作製されるグレーティ ング9,10) は高精度の周期構造をもち, 生じる回折光は構 造パラメー夕の選択によって容易に制御することができ る.

レーザー光を金属ターゲットへ照射したとき，固体中 では自由電子の共鳴振動で縦波のプラズモンが発生す る。このとき，固体表面に発生する“表面プラズモン”は 
横波であり, かつ, 入射レーザー光の偏光方向がP偏光 のとき入射面上でレーザー光とプラズモンの振動方向が 一致するため，両者はエネルギー結合できる可能性があ る。しかし，ターゲット界面方向のプラズモン波数は入 射レーザー光より常に大きい值をもつため, レーザー光 を平板金属ターゲットへ入射しただけでは表面プラズモ ンを励起することができない. 一方で，レーザー光をグ レーティングターゲットへ照射した場合，回折光のター ゲット界面方向の波数は溝周期の大きさに反比例してシ フトするため, 波数シフトさせた回折光と表面プラズモ ンの位相整合をおこなうことで, 両者のエネルギー結合 が可能となる。より具体的には, レーザー波長, 入射 角, グレーティング本数密度の組み合わせが共鳴条件を 満たす場合，表面プラズモンを励起 (Surface Plasmon Resonance: SPR)することができる ${ }^{11)}$. SPRは低強度レー ザー領域では, 励起された表面電場による信号増強に利 用され, 表面増強ラマン散乱などの生物・センサー用途 から, 高輝度LED, 高効率太陽電池などの産業用途にま で幅広い応用が期待されている

SPRの高強度レーザー領域への応用に関する研究例と しては，T. CeccottiらがSPRを用いた高エネルギープロ トン加速を実験的に示 し ${ }^{15)}$, M. Raynaud ${ }^{16)} ら$ と. Bigongiari $^{17,18)}$ らがそれぞれ表面電場の増強や効率の高い 高速電子生成をシミュレーションから示した報告などが 挙げられる. 高強度レーザーとナノ構造ターゲットが相 互作用した場合, ナノ構造内に強い電場が生じる「電場 集中」や構造の突起上に局所的な増強電場が生じる 「lightning rod effect」などの「構造の効果」によるエネル ギー吸収率の増加が考えられる。したがって，SPRによ る増強を評価するには「構造の効果」を分離した考察が必 要である. しかし, 上記の研究報告ではグレーティング ターゲットと平板ターゲットの単純比較に終始してお り,「構造の効果」と「SPRの効果」が混在した評価にとど まっている.

本研究では, 高強度レーザー領域において, SPRを利 用した高速電子ビームの高効率生成に関する成果を報告 する.SPRの共鳴条件を満たす状態において，グレー ティングターゲットへ高強度フェムト秒レーザーパルス を照射し, ターゲット董面に加速された高速電子ビーム のスペクトル計測をおこなった.SPRの共鳴条件におけ る電場の増強度がFDTDシミュレーションとPICシミュ レーションで再現されたこと, 実験で観測された高速電 子スペクトルはPICシミュレーション結果と相関がみら れたことを紹介し，高強度レーザー領域におけるSPRの 有効性について説明する。

\section{2. 高強度レーザーとグレーティングターゲットの 相互作用で発生する高速電子スペクトルの計測}

インドのタタ基礎研究所が所有する高強度フェムト秒 レーザーシステムを用いて実験をおこなった。 集光強度 は $10^{19} \mathrm{~W} / \mathrm{cm}^{2}$ ，パルス幅は30 fs，波長は800 nmである。 ターゲットは本数密度 500 本 $/ \mathrm{mm}$ のグレーティングと厚
み2.5 $\mu \mathrm{mt}$ の $\mathrm{Au}$ 薄膜ターゲットを用いた。ここで, グ レーティングは厚さ76 $4 \mathrm{mt}$ のポリエステル基板上に振幅 $100 \mathrm{~nm}$ の正弦波形状をもち, 表面は厚み $1 \mu \mathrm{mt}$ でAuコー ティングされている. Fig. 1に実験セットアップを示 す。高強度レーザー光をP偏光でターゲットへ $40^{\circ}$ 入射 し, ターゲット毫面垂直方向に加速された高速電子ビー ムのスペクトルをElectron spectrometer(ESM) で計測し た ${ }^{19)}$. ESMは磁場強度0.1 Tの磁石で電子の軌道を曲げ ることで，0.3-7.0 MeVのエネルギー範囲の計測が可能 である。高強度レーザーシステムのコントラストはメイ ンパルスの $10 \mathrm{ps}$ 前 で $4 \times 10^{-8}$, Amplified Spontaneous Emission (ASE) レベルは10 $10^{-8}$ あ゙あ。これは過去のナノ 構造ターゲットを用いた実験 $\left(10^{-6} \text { 程度 }\right)^{20)}$ と比較して高 コントラストであるため, 高強度メインパルス到達時点 にグレーティング形状が保持されていると考えられる.

グレーティングターゲットを用いたとき，表面プラズ モンの共鳴条件は

$$
\sin \theta+\frac{\lambda}{d}= \pm \sqrt{\frac{\varepsilon}{1+\varepsilon}}
$$

とあらわされる。ここで， $\theta$ はレーザー入射角，入は レーザー波長, $d$ はグレーティング周期, $\varepsilon$ は金属誘電率 の実部を示し，正負の符号はそれぞれ前方伝搬プラズモ ン波と後方伝搬プラズモンに対応する。 また，ターゲッ トがプラズマの場合, 共鳴条件は

$$
\sin \theta+\frac{\lambda}{d}= \pm \sqrt{\frac{1-n_{e} / n_{c}}{2-n_{e} / n_{c}}}
$$

と書き直すこともできる。ここで， $n_{\mathrm{e}}$ は固体ターゲット の電子密度, $n_{\mathrm{c}}$ はプラズマの臨界密度である $(\lambda=800 \mathrm{~nm}$ で $\left.n_{\mathrm{c}}=1.73 \times 10^{21} \mathrm{~cm}^{-3}\right)$. 本研究では, 「構造の効果」と 「SPRの効果」を示すグレーティングターゲットと一切の 増強効果をもたない薄膜ターゲットとの電子スペクトル の比較をおこなった。

グレーティングターゲットと薄膜ターゲットの高速電 子スペクトル計測結果をFig. 2に示す。スペクトルを指 数関数でフィッティングしたスロープ温度結果はグレー ティングでは $80 \mathrm{keV}( \pm 0.3 \mathrm{keV})$, 薄膜ターゲットは $13.6 \mathrm{keV}( \pm 0.3 \mathrm{keV})$ である。ここで括弧内の值はフィッ ティング誤差を示す.グレーティングは薄膜ターゲット に対して約16倍の個数増倍を示した。また裏面にイメー ジングプレートを置いて電子の放出分布を計測すると, 同様に5.8倍の信号強度の増加が得られた ${ }^{21)}$. Fig. 2のイ

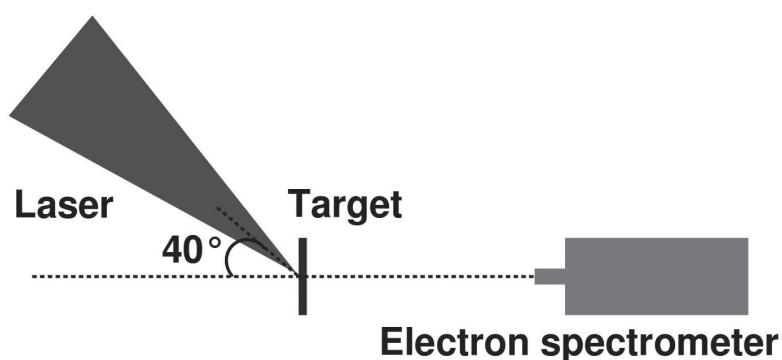

Fig. 1 Experimental setup. Electron spectrometer (ESM) is installed along the target normal to measure the spectrum of the emitted fast electron beam. 


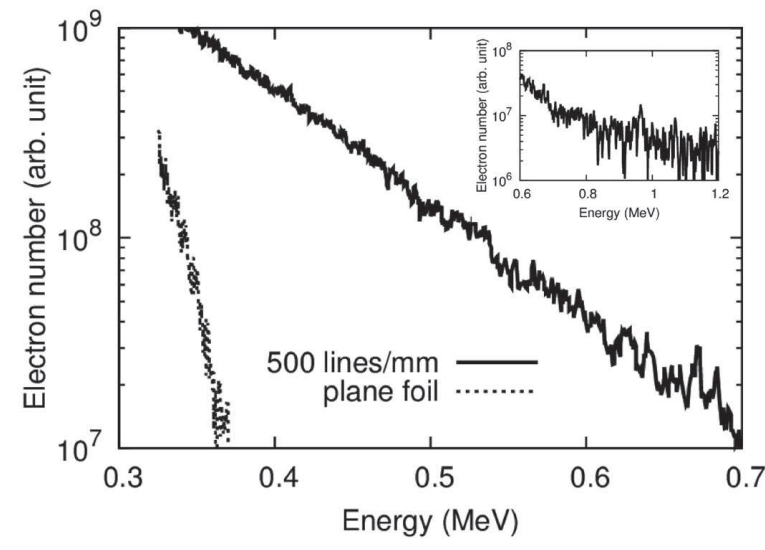

Fig. 2 Electron spectra for grating and plane foil targets in the experiment. The inset shows the higher energy component of the spectrum of the grating target.

ンセットにグレーティングにおける電子スペクトルの高 エネルギー部分を示し，そのスロープ温度は $480 \mathrm{keV}$ $( \pm 30 \mathrm{keV})$ であった。

\section{3. シミュレーションを用いた表面増強電場と 高速電子スペクトルの評価}

Finite Difference Time Domain(FDTD) シミュレーショ ン ${ }^{22)}$ を用い, グレーティングが示す「構造の効果」と 「SPRの効果」による増強度を評価した。 中心波長 $800 \mathrm{~nm}$ のガウシアンパルスをグレーティングターゲットへ $40^{\circ}$ 入射したとき，得られた反射率と前方伝搬プラズモンの 電場増強度の本数密度に対する依存性をFig. 3に示す。

Fig. 3より，500本 $/ \mathrm{mm}$ のきにSPRの共鳴条件を満たす ため, 反射率の急激な減少と前方プラズモン波の電場増 強が発生した。また，2000本/mmでも反射率の減少がみ られるが, これは後方伝搬プラズモンの共鳴条件を満た すためである。次に本数密度 $333 ， 500 ， 1000$ 本 $/ \mathrm{mm}$ のグ レーティングと平板ターゲットにおける電場強度分布の シミュレーション結果をFig. 4に示す. それぞれの本数 密度における強度分布の最大值を比較した結果, 平板

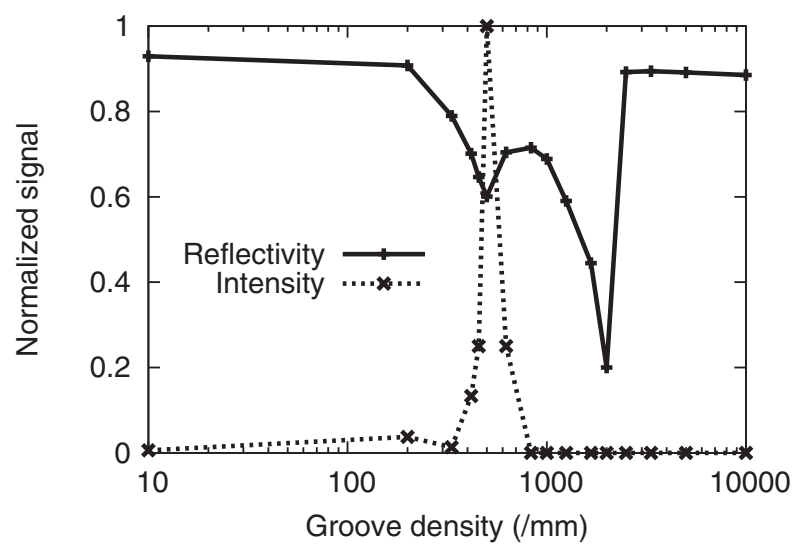

Fig. 3 FDTD simulation results: Dependence of the intensities of reflected and forward propagating waves on the groove density of grating targets.
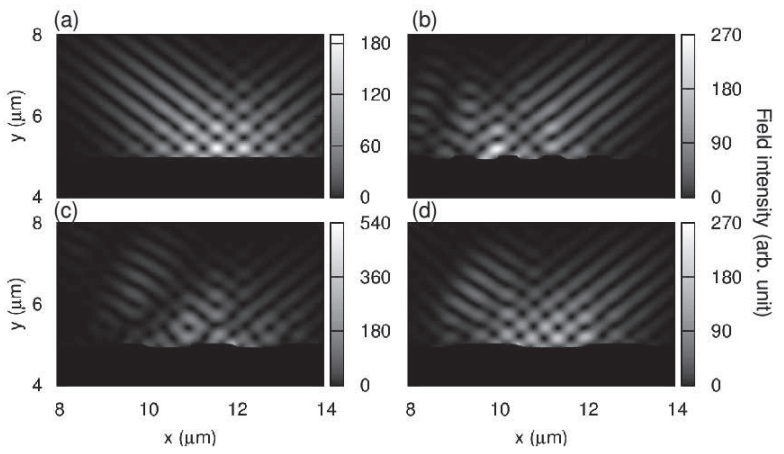

Fig. 4 Intensity distributions of electric field on the surface of (a) plane target, (b) 1000 lines/mm, (c) 500 lines/mm and (d) 333 lines/mm in the FDTD simulation. (a)

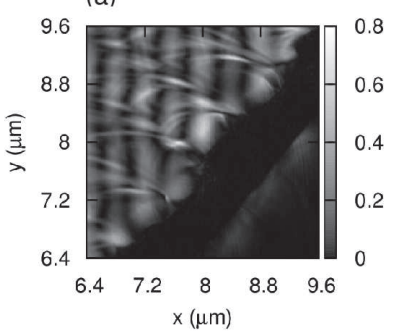

(b)

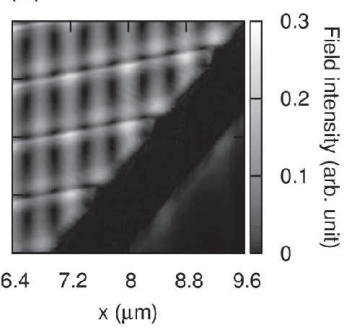

Fig. 5 Intensity distributions of electric field for (a) 500 lines/mm grating and (b) plane foil target in the PIC simulation. The scale bar shows the value normalized by $10^{20} \mathrm{~W} / \mathrm{cm}^{2}$.

ターゲットに対して, 333, 1000本/mmの増強度は $\eta^{2}=270 / 190=$ 約 1.42 倍であり，500本 $/ \mathrm{mm}$ の増強度は約 2.84倍であった。ここで，上記の増強度はそれぞれ「構 造の効果 $\left(\eta^{2}=1.42\right) 」$ と構造とSPRの両方の効果 $\left(\eta^{2}=2.84\right) 」$ に対応し, かつ本数密度 500 本 $/ \mathrm{mm}$ は333, 1000 本 $/ \mathrm{mm}$ の間であるため, 純粋なSPRによる増倍率は 2倍となる。

続いて, 高強度レーザーとグレーティングの相互作用 を模擬するため, 2次元のParticle-In-Cell (PIC) シミュ レーションを扢なった ${ }^{23)}$. セルサイズを入/64 $=12.5 \mathrm{~nm}$, ターゲットを $\mathrm{H}^{+}$とし, 配置する粒子個数を 100 particles/cell, 固体密度を $43 n_{\mathrm{c}}$ とし, 厚みを $1 \mu \mathrm{mt}$ とし た。ここで, PICでは金属固有のパラメータから計算さ れる誘電分極の効果を含まないため, SPRによる電場増 強をシミュレーションできない可能性がある。実際，本 論文で用いたXOOPIC ${ }^{21,23)}$ では表面を伝播するプラズモ ン波は空間分解能を十分小さく(数nm) とった場合でも 観測できなかった。本論文ではPICがSPRを再現しない ことを前提とし, FDTDシミュレーションから導出した 2倍のSPRによる増強度を用い, グレーティングター ゲットに対するレーザー強度を $2 \times 10^{19} \mathrm{~W} / \mathrm{cm}^{2}$ とした。 他のパラメータは実験条件と同じである。Fig. 5にグ レーティングターゲットと平板ターゲットの相互作用時 の電場強度分布のシミュレーション結果を示す. ター ゲット表面の電場強度值を比較した結果, グレーティン グターゲットは平板ターゲットに対して2.67倍の利得を 


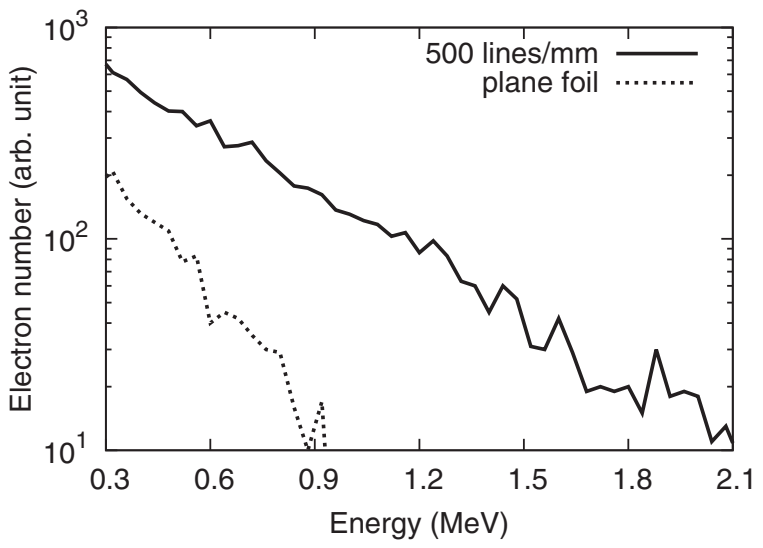

Fig. 6 Electron spectra for grating and plane foil targets along the target rear normal in the PIC simulation.

示した。この結果はFDTDシミュレーションで得た 2.84 倍とほぼ一致している。しかし, Fig. 5の結果では表面 プラズマ波の波動的な電場分布は観測されておらず，ま た，2倍の入射レーザー強度を用いることがSPRによる 局所電場の増大を直接模擬しているわけではないことに 注意する. Fig. 6に電子スペクトルのPICシミュレーショ ン結果を示す。グレーティングと平板ターゲットのス ロープ温度はそれぞれ465 $\mathrm{keV}( \pm 8 \mathrm{keV})$ と $229 \mathrm{keV}$ ( $\pm 11 \mathrm{keV})$ である。ここで, Fig. 2の実験結果とFig. 6の シミュレーション結果を比較すると, それぞれのスペク トルの傾向は良い一致がみられる一方で, シミュレー ション結果の方が両方のターゲットに関して共にスロー プ温度が高いことがわかる，最も単純な比較として，両 者の平板ターゲットのスロープ温度を比べた場合であっ ても, 実験結果の $13.6 \mathrm{keV}$ に対してシミュレーション結 果は229 keVであり，大きく異なっている。 この差は， 計算機の制限により実験とシミュレーションのターゲッ 卜厚みが80倍異なっている上, シミュレーションがター ゲット董面近傍の電子を計測した結果であるのに対し， 実験は固体ターゲット裏面に生じる電磁場の影響を受け た後に計測器に辿り着いた電子のスペクトルを計測した 結果であることが原因と考えられる ${ }^{24)}$. しかしながら， PICシミュレーションにおけるグレーティングターゲッ トと平板ターゲットの電子個数比は 10 倍であり, 実験結 果の16倍とおおよその一致がみられ，かつスペクトルの 傾向が一致することから，2つの結果には相関があると 考えられる。また，グレーティングのスペクトルの高温 成分に対するスロープ温度は, 実験值の $480 \mathrm{keV}$ とシ ミュレーション值の $465 \mathrm{keV} に 一$ 致がみられた. Fig. 7に レーザー軸方向スペクトルのシミュレーション結果を示 す。グレーティングターゲットと平板ターゲットは2温 度成分を示し，これらの高温成分のスロープ温度はそれ ぞれ1.40 MeV( $(77 \mathrm{keV})$ と704 keV $( \pm 21 \mathrm{keV})$ であった。 ここで, 加速電子の平均エネルギーとレーザー場が電子 に及ぼすポンデロモーティブカが等しいとみなしたス ケーリングを用いると ${ }^{25)}$, レーザー強度 $10^{19} \mathrm{~W} / \mathrm{cm}^{2}$ と $2 \times 10^{19} \mathrm{~W} / \mathrm{cm}^{2}$ に対するスケーリング值は706 keVと $1.42 \mathrm{MeV}$ であり, シミュレーション結果との一致がみ

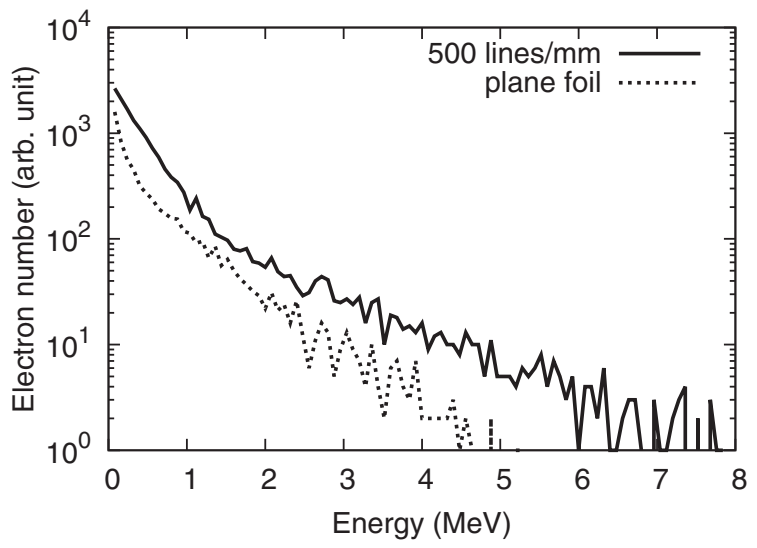

Fig. 7 Electron spectra for grating and plane targets along the laser axis in the PIC simulation.

られ，グレーティングターゲットを用いたとき，生成さ れる高速電子は, ナノ構造表面の強い局所電場が電子に 及ぼすポンデロモーティブ力によって加速された可能性 がある25)。

\section{4. 結 論}

本研究では, 表面プラズモンの共鳴条件を満たした状 態において，高強度レーザーとグレーティングターゲッ 卜の相互作用で加速される高速電子の高効率生成に関す る報告をおこなった。高速電子スペクトル計測の結果, グレーティングターゲットを用いた場合は薄膜ターゲッ 卜に対して約16倍の個数比が得られ, PICシミュレー ションから得られた10倍の数值とほぼ一致した。 した がって, FDTDシミュレーションで計算した増強度を PICシミュレーションの入射レーザー強度に取り入れる ことで，グレーティングと平板ターゲットの実験結果か ら得られた高速電子数の倍増を定性的に説明することが できた，FDTDシミュレーション結果から， 500 lines $/ \mathrm{mm}$ では反射率の急激な減少と表面電場の増大が同時に得ら れ，表面プラズモン共鳴の特徵的な性質が示された。 た，レーザー軸方向に拈けるスペクトルの高温成分ス ロープ温度がポンデロモーティブのスケーリング值と一 致した．表面構造上の強い局所電場によるポンデロモー ティブカが高速電子を加速した可能性を示した.

この研究は, 初めて高強度レーザー領域において, 「構造による効果」と「SPRによる効果」を分離した上で表 面プラズモン共鳴の有効性を評価しており，今後，ナノ 構造を用いた高効率・高品質なビーム生成の研究に応用 が期待される。

\section{謝 辞}

本研究は, 科学研究費補助金(基盤研究A (22246122), 基盤研究B (23360412))，X線自由電子レーザー重点戦略 研究課題 (12005014), アジア研究教育拠点事業・高強度 フォトンを用いる高エネルギー密度状態の科学 (ASHULA)の支援を受けておこなわれた. 


\section{参考文献}

1) M. Tabak, J. Hammer, M. E. Glinsky, W. L. Kruer, S. C. Wilks, J. Woodworth, E. M. Campbell, and M. D. Perry: Phys. Plasmas 1 (1994) 1626.

2) R. Kodama: J. Plasma Fusion Res. 81 (2005) 105.

3) J. Fuchs, P. Antici, E. D. Humieres, E. Lefebvre, M. Borghesi, E. Brambrink, C. A. Cecchetti, M. Kaluza, V. Malka, M. Manclossi, et al.: Nature Phys. 2 (2006) 48.

4) E. L. Clark, K. Krushelnick, J. R. Davies, M. Zepf, M. Tatarakis, F. N. Beg, A. Machacek, P. A. Norreys, M. I. K. Santala, I. Watts, et al.: Phys. Rev. Lett. 84 (2000) 670.

5) M. M. Murnane, H. C. Kapteyn, M. D. Rosen, and R. W. Falcone: Science 251 (1991) 531

6) G. Chatterjee, P. K. Signh, S. Ahmed, A. P. L. Robinson, A. D. Lad, S. Mondal, V. Narayanan, I. Srivastava, N. Koratkar, J. Pasley, et al.: Phys. Rev. Lett. 108 (2012) 235005.

7) A. L. Lei, K. A. Tanaka, R. Kodama, G. R. Kumar, K. Nagai, T. Norimatsu, T. Yabuuchi, and K. Mima: Phys. Rev. Lett. 96 (2006) 255006.

8) H. A. Sumeruk, S. Kneip, D. R. Symes, I. V. Churina, A. V. Beloipetski, G. Dyer, J. Landry, G. Bansal, A. Bernstein, T. D. Donnelly, et al.: Phys. Plasmas 14 (2007) 062704.

9) S. Kahaly, S. K. Yadav, W. M. Wang, S. Sengupta, Z. M. Sheng, A. Das, P. K. Kaw, and G. R. Kumar: Phys. Rev. Lett. 101 (2008) 145001 .

10) W. M. Wang, Z. M. Sheng, and J. Zhang: Phys. Plasmas 15 (2008) 030702 .

11) W. L. Barnes, A. Dereux, and T. W. Ebbesen: Nature 424 (2003) 824.

12) A. Polyakov, S. Cabrini, S. Dhuey, B. Harteneck, P. J. Schuck, and H. A. Padmore: Appl. Phys. Lett. 98 (2011) 203104.

13) J. Dostalek and J. Homola: Sensors and Actuators B 129 (2008) 303.

14) J. M. Yuen, N. C. Shah, J. T. Walsh, M. R. Glucksberg, and R. P. V. Duyne: Anal. Chem. 82 (2010) 8382.

15) T. Ceccotti, V. Floquet, A. Sgattoni, A. Bigongiari, O. Klimo, M. Raynaud, C. Riconda, A. Heron, F. Baffigi, L. Labate, et al.: Phys. Rev. Lett. 111 (2013) 185001.

16) M. Raynaud, J. Kuperszlych, C. Riconda, J. C. Adam, and Heron: Phys. Plasmas 14 (2007) 092702.

17) A. Bigongiari, M. Raynaud, C. Riconda, A. Heron, and A. Macchi: Phys. Plasmas 18 (2011) 102701.

18) A. Bigongiari, M. Raynaud, C. Riconda, and A. Heron: Phys. Plasmas 20 (2013) 052701

19) K. A. Tanaka, T. Yabuuchi, T. Sato, R. Kodama, Y. Kitagawa, T. Takahashi, T. Ikeda, Y. Honda, and S. Okuda: Rev. Sci. Instrum. 76 (2005) 013507.

20) P. K. Singh, I. Chakraborty, G. Chatterjee, A. Adak, A. D. Lad, P. Brijesh, P. Ayyub, and G. R. Kumar: Phys. Rev. ST Accel. Beams 16 (2013) 063401.

21) Y. Mishima, H. Habara, P. K. Singh, A. Adak, G. Chatterjee, A. D. Lad, S. Tata, P. Brijesh, M. Dalui, T. M. Trivikram, et al.: The 12th Asia Pacific Physics Conference, Chiba, July (2013) p. 339.

22) A. F. Oskooi, D. Roundry, M. Ibanescu, P. Bermel, J. D. Joannopoulos, and S. G. Johnson: Comp. Phys. Commun. 181 (2010) 687.

23) J. P. Verboncoeur, A. B. Langdon, and N. T. Gladd: Comp. Phys. Commun. 87 (1995) 199.

24) H. Habara, K. Ohta, K. A. Tanaka, G. R. Kumar, M. Krishnamurthy, S. Kahaly, S. Mondal, K. Bhuyan, R. Rajeev, et al.: Phys. Rev. Lett. 104 (2010) 055001.

25) S. C. Wilks, W. L. Kruer, M. Tabak, and A. B. Langdon: Phys. Rev. Lett. 69 (1992) 1382. 